Journal of

Molecular Microbiology

and Biotechnology
J Mol Microbiol Biotechnol 2009;17:124-135

DOI: $10.1159 / 000226589$

Published online: June 26, 2009

\title{
Interaction between Plants and Bacteria: Glucosinolates and Phyllospheric Colonization of Cruciferous Vegetables by Enterobacter radicincitans DSM 16656
}

\author{
Monika Schreiner Angelika Krumbein Silke Ruppel \\ Leibniz Institute of Vegetable and Ornamental Crops Grossbeeren and Erfurt e.V., Grossbeeren, Germany
}

\begin{abstract}
Key Words
Phytochemicals - Alkenyl glucosinolates - Methylsulfinyl glucosinolates $\cdot$ 2-Phenylethyl glucosinolate $\cdot$ Persistence of plant growth-promoting bacteria $\cdot$ Real-time PCR
\end{abstract}

\begin{abstract}
For determining interactive plant-bacterial effects between glucosinolates and phyllospheric colonization by a plant growth-promoting strain, Enterobacter radicincitans DSM 16656 , in cruciferous vegetables, the extent of bacterial colonization was assessed in 5 cruciferous vegetables (Brassica juncea, Brassica campestris, Brassica oleracea var. capitata, Brassica rapa var. alboglabra, Nasturtium officinale) using a species-specific TaqMan ${ }^{\mathrm{TM}}$ probe and quantitative real-time PCR. Colonization ability of inoculated E. radicincitans in the phyllosphere of these species varied from inability to colonize $B$. rapa up to a very good colonization rate of $B$. campestris. In addition to morphological factors and other plant compounds, the colonization rate was affected by different individual aromatic and aliphatic glucosinolates and their concentration, revealing that both plant pathogens and plant growth-promoting bacteria were affected by glucosinolates in their colonization behavior. In contrast, after $E$. radicincitans inoculation neither the total nor the individual glucosinolate concentrations in the phyllosphere of the 5 cruciferous species were affected, indicating that the non-
\end{abstract}

pathogenic E. radicincitans might cause only poor cell damage by metabolizing plant cell components and does not induce a plant defense response and thus subsequently an increased glucosinolate concentration in the phyllosphere. Moreover, E. radicincitans induced no stimulation of indole glucosinolate biosynthesis by additional bacterial auxin supply.

Copyright $\odot 2009$ S. Karger AG, Basel

\section{Introduction}

Members of the family Brassicaceae are horticulturally important crop plants and highly consumed vegetables [Behr, 2006; Monteiro and Lunn, 1999]. These cruciferous vegetables are characterized by glucosinolates, a group of phytochemicals found exclusively in plants of the order Brassicales, including the family Brassicaceae [Halkier and $\mathrm{Du}, 1997$ ] and in the genus Drypteres belonging to the Euphorbiaceae [Rodman et al., 1998]. Plant species strongly influences bacterial colonization, leading to pronounced differences in community composition [Janczik et al., 2006; Lindow et al., 2002]. In Brassicaceae, this effect can be explained by the genotypically different formation of microbially affected secondary plant metabolites, mainly glucosinolates, and hence varying concentrations and composition of these

\section{KARGER \\ Fax +4161306 1234 \\ E-Mail karger@karger.ch}

www.karger.com
(C) 2009 S. Karger AG, Basel

$1464-1801 / 09 / 0173-0124 \$ 26.00 / 0$

Accessible online at:

www.karger.com $/ \mathrm{mmb}$
Monika Schreiner

Leibniz Institute of Vegetable and Ornamental Crops Grossbeeren and Erfurt e.V

Theodor-Echtermeyer-Weg 1

DE-14979 Grossbeeren (Germany)

Tel. +4933701 78304, Fax +49 33701 55391, E-Mail schreiner@igzev.de 
Table 1. Structural formulae of glucosinolates assessed in this study

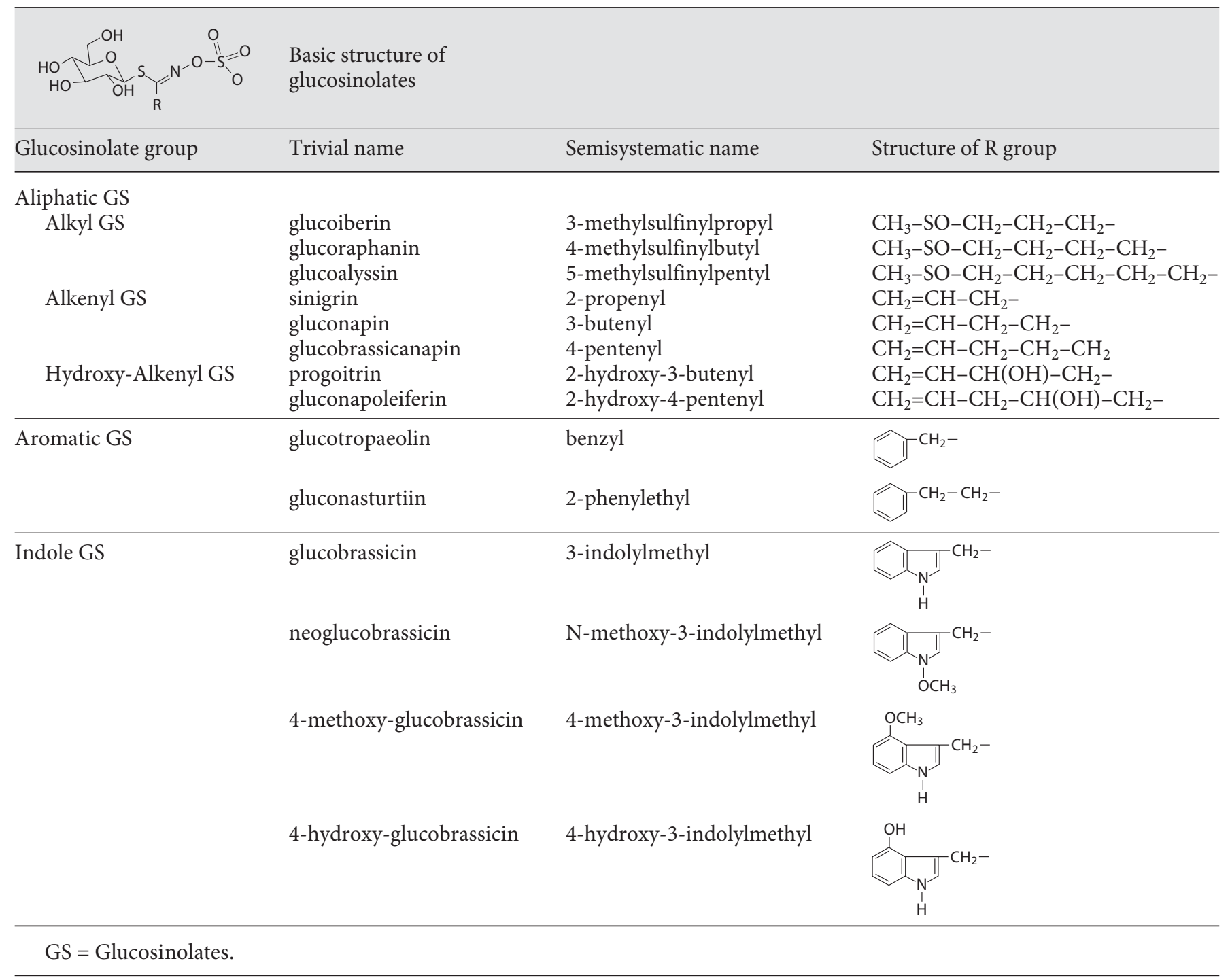

phytochemicals. It was demonstrated by Ruppel et al. [2008] that the bacterial population density was positively correlated to the alkenyl glucosinolates 2-propenyl, 3butenyl and 4-pentenyl whereas the aromatic glucosinolate 2-phenylethyl showed a negative correlation to the phyllospheric bacterial population size. Moreover, in plant-bacterial interaction, glucosinolates are involved in the plant defense response against microbial pathogen attack [Mikkelsen et al., 2003] resulting in reduced bacterial colonization and growth [Brader et al., 2001, 2006; O'Callaghan et al., 2000; Tierens et al., 2001]. In the process of chemical defense, the synthesis of structurally different aliphatic, aromatic, and indole glucosinolates (table 1) changes as a response to a particular pathogen [Brader et al., 2006].

While there are a few reports on glucosinolate-affected synthesis due to specific bacteria in the rhizosphere [e.g. Bending and Lincoln, 2000; O'Callaghan et al., 2000], little is known about the exact interaction between individual glucosinolate concentration and colonization of the phyllosphere by plant growth-promoting bacteria (PGPB).

Enterobacter radicincitans DSM 16656 (formerly Pantoea agglomerans) is a deeply investigated and established PGPB strain characterized by its ability to fix atmospheric nitrogen and produce phytohormones such as auxins 
Fig. 1. Bacterial growth of E. radicincitans DSM16656 with glucosinolate standards (2-propenyl and benzyl), glucose + sucrose and Brassica plant extracts as $\mathrm{C}$ sources

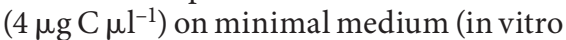
experiment). Bacterial growth response was calculated relatively to the growth on glucose + sucrose $(=100 \%)$. Bars indicate the standard deviation of the mean values from three replicates.

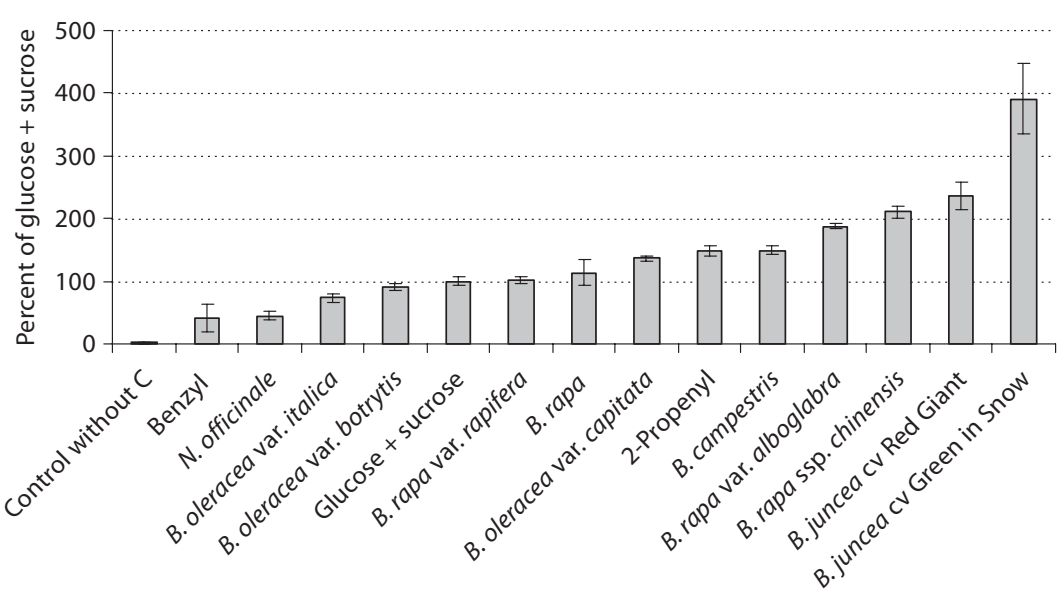

and cytokinins [Kämpfer et al., 2005; Scholz-Seidel and Ruppel, 1992]. E. radicincitans is able to improve root and shoot growth and the yield of winter wheat, barley, maize, pea [Höflich and Ruppel, 1994; Ruppel, 2000] and Brassica oleracea [Ruppel and Wernitz, 2004; Ruppel et al., 2006]. This bacterial strain was shown to colonize the endophyllosphere of wheat without inducing plant defense reactions [Ruppel et al., 1992]. Brassica species could probably respond differently to colonization by $E$. radicincitans: first, glucosinolate concentration could increase in the colonized phyllosphere due to the plant's defense response; second, indole glucosinolate concentration might increase as a consequence of additional auxin supply from $E$. radicincitans since the additive auxin might induce predominant metabolization of indole3 -acetaldoxime to indole glucosinolates as auxin and indole glucosinolates are both derived from the key metabolite indole-3-acetaldoxime [Bak et al., 2001].

Increasing glucosinolates in the plant's tissue have generated considerable pharmacological interest due to their human health-promoting effects, particularly anticarcinogenic properties [Talalay and Fahrey, 2001]. Applications of biological elicitors could be effective in increasing desired phytochemicals [Schreiner and Huyskens-Keil, 2006].

Therefore, the aim of the present study was to examine whether the colonization ability of the PGPB strain E. radicincitans is uniform in 5 different cruciferous vegetables. We further tested whether the colonization ability is related to different glucosinolate concentrations and composition, especially to the alkenyl and aromatic glucosinolates, which were shown to affect the native bacterial phyl- lospheric population [Ruppel et al., 2008] in the phyllosphere of these plants and probably modified by other plant compounds potentially affecting the colonization ability of E. radicincitans. In addition, we wanted to determine whether in this specific plant-bacterial interaction, i.e. cruciferous vegetables $-E$. radicincitans, the glucosinolate concentration could be promoted by E. radicincitans colonization, thereby suggesting phytochemical stimulation by additional bacterial auxin production or enhanced plant defense response induced by E. radicincitans.

To verify the results of in vivo plant experiments, plant extracts and glucosinolate standards were monitored for $E$. radicincitans growth responses in pure culture experiments. The colonization ability of $E$. radicincitans in the phyllosphere was assessed using a species-specific primer $\mathrm{TaqMan}^{\mathrm{TM}}$ probe and quantitative real-time PCR. To our knowledge, this is the first published study using quantitative real-time PCR analysis to quantify targets of $E$. radicincitans in the phyllosphere of plants performed in conjunction with phytochemical analysis to examine the interaction between glucosinolates and bacterial colonization of the plant phyllosphere as well as the phytochemical impact of E. radicincitans.

\section{Results}

\section{Specific Bacterial Strain Responses on Glucosinolate}

Standards and Plant Extracts

The in vitro experiment showed a positive growth response of $E$. radicincitans on all added substrates in minimal medium (fig. 1). All plant extracts and both tested 
Table 2. Individual glucosinolate concentration $\left(\mathrm{mg} 100 \mathrm{~g}^{-1} \mathrm{fm}\right)$ in the leaf extract of 11 cruciferous plant species (in vitro experiment)

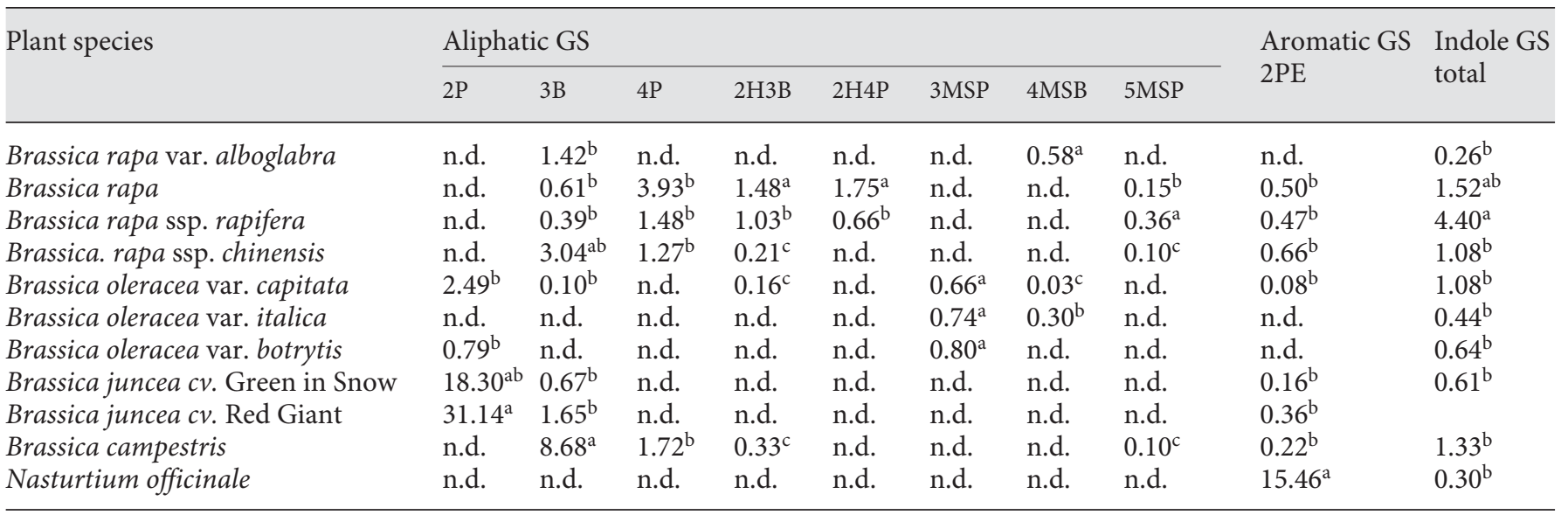

$\mathrm{GS}=$ Glucosinolate; $\mathrm{fm}=$ fresh matter; $2 \mathrm{P}=2$-propenyl; $3 \mathrm{~B}=3$-butenyl; $4 \mathrm{P}=4$-pentenyl; $2 \mathrm{H} 3 \mathrm{~B}=2$-hydroxy-3-butenyl; $2 \mathrm{H} 4 \mathrm{P}=3$ hydroxy-4-pentenyl; 3MSP = 3-methylsulfinylpropyl; 4MSB = 4-methylsulfinylbutyl; 5MSP = 5-methylsulfinylpentyl; 2PE = 2-phenylethyl; n.d. = not detectable. Each value represents the mean of 9 samples. Mean values are compared for each individual glucosinolate. Values followed by the same superscript are not significantly different.

Table 3. Total glucosinolate concentration, major aliphatic, aromatic and indole glucosinolates in 5 cruciferous plant species (plant pot experiment)

\begin{tabular}{|c|c|c|c|c|c|c|c|c|c|c|c|c|}
\hline \multirow[t]{3}{*}{ Plant species } & \multicolumn{2}{|c|}{ Total GS } & \multicolumn{6}{|c|}{ Major aliphatic GS } & \multirow{2}{*}{\multicolumn{2}{|c|}{$\frac{\text { Major aromatic GS }}{2 \mathrm{PE}}$}} & \multirow{2}{*}{\multicolumn{2}{|c|}{$\frac{\text { Major indole GS }}{3 \text { IM }}$}} \\
\hline & & & \multicolumn{2}{|l|}{$2 \mathrm{P}$} & \multicolumn{2}{|l|}{$3 \mathrm{~B}$} & \multicolumn{2}{|l|}{$4 \mathrm{MSB}$} & & & & \\
\hline & $\mathrm{mg} \mathrm{g}^{-1} \mathrm{~d}_{\mathrm{r}}$ & & $\mathrm{mg} \mathrm{g}^{-1} \mathrm{dm}$ & $\%$ & $\mathrm{mg} \mathrm{g}^{-1} \mathrm{dm}$ & $\%$ & $\mathrm{mg} \mathrm{g}^{-1} \mathrm{dm}$ & $\%$ & $\mathrm{mg} \mathrm{g}^{-1} \mathrm{dm}$ & $\%$ & $\mathrm{mg} \mathrm{g}^{-1} \mathrm{dm}$ & $\%$ \\
\hline Brassica rapa var. alboglabra & $1.85^{\mathrm{c}}$ & $\mathrm{L}$ & $0.15^{\mathrm{c}}$ & 8 & $0.72^{\mathrm{b}}$ & 38.9 & $0.37^{\mathrm{a}}$ & 20.0 & $0.02^{c}$ & 1.1 & $0.04^{\mathrm{c}}$ & 2.2 \\
\hline Brassica juncea & $4.27^{\mathrm{b}}$ & M & $3.93^{\mathrm{a}}$ & 9 & $0.16^{\mathrm{b}}$ & 3.8 & n.d. & 0.0 & $0.12^{\mathrm{b}}$ & 2.8 & $0.03^{c}$ & 0.7 \\
\hline Nasturtium officinale & $7.05^{\mathrm{a}}$ & $\mathrm{H}$ & n.d. & 0 & n.d. & 0.0 & n.d. & 0.0 & $6.63^{\mathrm{a}}$ & 94.0 & $0.15^{\mathrm{a}}$ & 2.1 \\
\hline Brassica oleracea var. capitata & $1.76^{\mathrm{c}}$ & $\mathrm{L}$ & $1.07^{\mathrm{b}}$ & 6 & $0.10^{\mathrm{b}}$ & 5.7 & $0.07^{b}$ & 4.0 & $0.03^{c}$ & 1.7 & $0.12^{\mathrm{ab}}$ & 6.8 \\
\hline Brassica campestris & $5.60^{\mathrm{ab}}$ & $\mathrm{H}$ & $0.03^{c}$ & 1 & $4.76^{\mathrm{a}}$ & 85.0 & n.d. & 0.0 & $0.70^{\mathrm{b}}$ & 12.5 & $0.07^{\mathrm{bc}}$ & \\
\hline
\end{tabular}

GS = Glucosinolates; $\mathrm{DM}=$ dry matter; $\mathrm{H}=$ high, $\mathrm{M}=$ medium, $\mathrm{L}=$ low concentrations of total glucosinolates; $2 \mathrm{P}=2$-propenyl; 3B = 3-butenyl; 4MSB = 4-methylsulfinylbutyl; 2PE = 2-phenylethyl; 3IM = 3-indolylmethyl; n.d. = not detectable. Each value represents the mean of 9 samples. Mean values are compared for each individual glucosinolate and glucosinolate group, respectively. Values followed by the same superscript are not significantly different.

glucosinolate standards (2-propenyl and benzyl) supported the growth of $E$. radicincitans in minimal medium compared to the control without carbon. As the growth of E. radicincitans was higher at 2-propenyl compared to the glucose + sucrose mixture, this aliphatic 2propenyl glucosinolate seems to be a preferred carbon source under limited nutrition conditions, whereas the aromatic benzyl glucosinolate led to the lowest bacterial growth. Comparing the growth response of $E$. radicinci- tans to the glucose + sucrose mixture, growth on 2-propenyl standard and on plant extracts containing a high 2-propenyl concentration (Brassica juncea cv. Green in Snow, B. juncea cv. Red Giant, B. oleracea var. capitata cv. Türkis) was increased by 50 and $290 \%$ (fig. 1, table 2). Plant extracts characterized by an increased 3-butenyl concentration (Brassica campestris, Brassica rapa ssp. chinensis) and 4-pentenyl concentration (B. rapa) also revealed strong bacterial growth (fig. 1 , table 2 ). In con- 
Table 4. Concentrations of phyllospheric carbon sources ( $\mathrm{mg} \mathrm{g}^{-1} \mathrm{dry}$ matter) in 5 cruciferous plant species (plant pot experiment)

\begin{tabular}{lllllll}
\hline Plant species & Glucose & Fructose & Sucrose & C & N & C/N \\
\hline Brassica rapa var. alboglabra & $61.00^{\mathrm{ab}}$ & $39.15^{\mathrm{a}}$ & $19.94^{\mathrm{a}}$ & $41.38^{\mathrm{a}}$ & $1.78^{\mathrm{b}}$ & $23.78^{\mathrm{ab}}$ \\
Brassica juncea & $37.82^{\mathrm{b}}$ & $27.52^{\mathrm{ab}}$ & $11.88^{\mathrm{bc}}$ & $39.89^{\mathrm{bc}}$ & $1.72^{\mathrm{b}}$ & $23.65^{\mathrm{ab}}$ \\
Nasturtium officinale & $21.13^{\mathrm{c}}$ & $16.14^{\mathrm{b}}$ & $7.30^{\mathrm{cd}}$ & $38.78^{\mathrm{c}}$ & $2.95^{\mathrm{a}}$ & $13.32^{\mathrm{b}}$ \\
Brassica oleracea var. capitata & $43.86^{\mathrm{ab}}$ & $30.37^{\mathrm{ab}}$ & $5.90^{\mathrm{d}}$ & $40.42^{\mathrm{ab}}$ & $1.62^{\mathrm{b}}$ & $25.62^{\mathrm{a}}$ \\
Brassica campestris & $70.64^{\mathrm{a}}$ & $18.11^{\mathrm{b}}$ & $13.77^{\mathrm{b}}$ & $39.36^{\mathrm{bc}}$ & $1.55^{\mathrm{b}}$ & $25.74^{\mathrm{a}}$ \\
\hline
\end{tabular}

$\mathrm{N}=$ Total nitrogen; $\mathrm{C}=$ total carbon. Each value represents the mean of 9 samples. Mean values are compared for each compound. Values followed by the same superscript are not significantly different.

Table 5. Concentrations of major flavonoids and carotenoids ( $\mathrm{mg} \mathrm{g}^{-1}$ dry matter) in 5 cruciferous plant species (plant pot experiment)

\begin{tabular}{llllll}
\hline Plant species & Quercetin & Kaempferol & Isorhamnetin & Lutein & $\beta$-Carotene \\
\hline Brassica rapa var. alboglabra & $0.43^{\mathrm{b}}$ & $1.94^{\mathrm{a}}$ & n.d. & $0.79^{\mathrm{b}}$ & $0.44^{\mathrm{b}}$ \\
Brassica juncea & $0.32^{\mathrm{b}}$ & $1.23^{\mathrm{b}}$ & $0.63^{\mathrm{b}}$ & $0.61^{\mathrm{c}}$ & $0.41^{\mathrm{b}}$ \\
Nasturtium officinale & $0.90^{\mathrm{a}}$ & $0.19^{\mathrm{c}}$ & n.d. & $0.92^{\mathrm{a}}$ & $0.39^{\mathrm{b}}$ \\
Brassica oleracea var. capitata & $0.54^{\mathrm{b}}$ & $2.02^{\mathrm{a}}$ & n.d. & $0.59^{\mathrm{c}}$ & $0.29^{\mathrm{c}}$ \\
Brassica campestris & $0.30^{\mathrm{b}}$ & $1.06^{\mathrm{b}}$ & $1.44^{\mathrm{a}}$ & $0.82^{\mathrm{ab}}$ & $0.56^{\mathrm{a}}$ \\
\hline
\end{tabular}

Each value represents the mean of 9 samples. Mean values are compared for each compound. Values followed by the same superscript are not significantly different. n.d. = Not detectable.

trast, the growth on benzyl and plant extracts containing high concentrations of 2-phenylethyl (Nasturtium officinale) was about $60 \%$ lower (fig. 1, table 2).

Concentration and Composition of Glucosinolates and Other Carbon Sources in Cruciferous Plants

The 5 investigated cruciferous species varied in their total and individual glucosinolate concentrations resulting in low, medium, or high glucosinolate levels (table 3). Moreover, these species differed in their composition, especially in a particular major aliphatic (2-propenyl, 3-butenyl, 4-methylsulfinylbutyl) or aromatic (benzyl) glucosinolate combined with varying indole glucosinolate concentrations $\left(0.04-0.20 \mathrm{mg} \mathrm{g}^{-1}\right.$ dry matter, DM) and percentages $(0.3-8.5 \%)$ (table 3 ). The concentration of the predominant aliphatic or aromatic glucosinolate ranged from 0.37 to $6.63 \mathrm{mg} \mathrm{g}^{-1} \mathrm{DM}$ which translates to between 20 and $94 \%$ of the total glucosinolate content (table 3 ).

The investigated cruciferous species also differed in their concentrations of other carbon sources (table 4). $B$. rapa var. alboglabra showed the highest concentration in phyllospheric fructose, sucrose and total carbon whereas glucose was the predominant monosaccharide in $B$. campestris compared to all other investigated cruciferous species. The lowest concentration in mono- and disaccharides as well as in total carbon was measured in $N$. officinale, resulting in the lowest $\mathrm{C} / \mathrm{N}$ ratio. The highest $\mathrm{C} / \mathrm{N}$ ratio was shown by $B$. oleracea var. capitata and $B$. campestris.

\section{Concentrations of Flavonoids and Carotenoids in Cruciferous Plants}

The major flavonoids in the investigated cruciferous species were quercetin, kaempferol, and isorhamnetin as well as lutein and $\beta$-carotene were the predominant carotenoids. The cruciferous species exhibited different flavonoid concentrations with the highest quercetin concentration in $N$. officinale, and highest kaemperol concentrations in B. rapa var. alboglabra and B. oleracea var. capitata (table 5). Additionally, isorhamnetin occurred in $B$. juncea and B. campestris. With respect to the carotenoids, N. officinale and B. campestris were characterized 


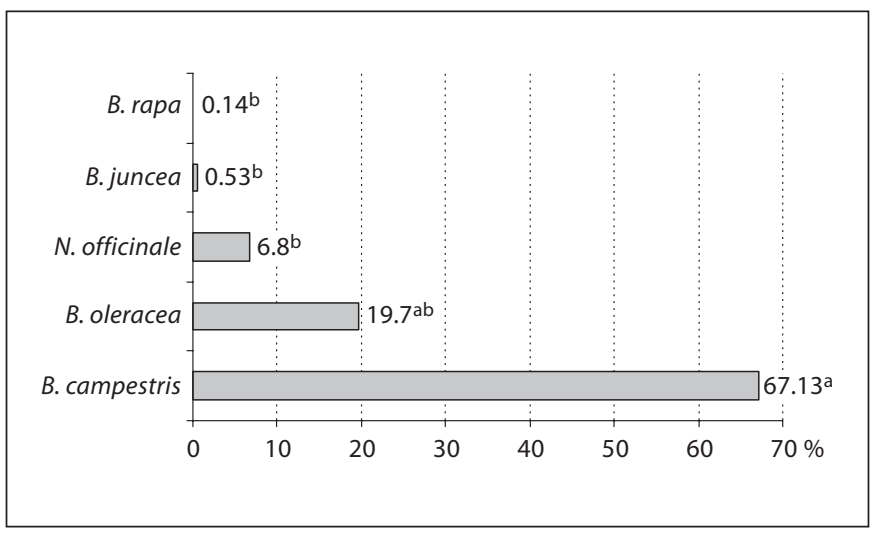

Fig. 2. Colonization ability of E. radicincitans bacterial cells inoculated into the phyllosphere of 5 cruciferous species (plant pot experiment). Quantification of E. radicincitans in the inoculated treatment sample was relative to the non-inoculated control sample and normalized to the reference TEF gene (mean values of 3 replicates, different superscripts indicate significant differences between plants).

Table 6. Multiple regression analysis to determine the effect of aromatic 2-phenylethyl glucosinolate and alkenyl glucosinolates (2-propenyl, 3-butenyl and 4-pentenyl) in 11 cruciferous plant extracts (in vitro experiment) on colonization ability of E. radicincitans $(\mathrm{n}=33), \mathrm{r}=0.830$

\begin{tabular}{lll}
\hline Variables & $\begin{array}{l}\text { Standardized regression } \\
\text { coefficients }(\beta)\end{array}$ & p level $^{1}$ \\
\hline 2-Propenyl & 0.83 & 0.000 \\
3-Butenyl & 0.24 & 0.008 \\
4-Pentenyl & -0.03 & 0.718 \\
2-Phenylethyl & -2.21 & 0.021 \\
\hline
\end{tabular}

${ }^{1}$ Significant at $\mathrm{p} \leq 0.05$.

by increased lutein concentrations (table 5). In addition, $B$. campestris also comprised the highest $\beta$-carotene concentration. B. oleracea var. capitata showed the lowest carotenoid concentrations (table 5).

Colonization by Inoculated E. radicincitans Cells of the Phyllosphere of Cruciferous Plants

The inoculated E. radicincitans cells were able to colonize the phyllosphere of $B$. campestris in high concentrations even after a plant growth period of about 6 weeks (fig. 2). In B. oleracea var. capitata leaves, only weak colonization was found; however, the introduced bacterial cells did not significantly colonize the plant phyllosphere of the other three cruciferous plants (B. juncea, B. rapa var. alboglabra, N. officinale).

Effect of E. radicincitans Inoculation on Glucosinolate Concentration and Other Plant Compounds in Cruciferous Plants

Neither the total glucosinolate concentration nor the individual glucosinolates in the phyllosphere of the investigated 5 cruciferous species were affected by $E$. radicincitans inoculation (data not shown). Overall, E. radicincitans inoculation did not alter glucosinolate concentration or composition whether the phyllosphere was strongly colonized or not.

Additionally, the phyllospheric concentration of the compounds used as further carbon sources by E. radicincitans (sugars, total carbon) and other phytochemicals potentially affecting E. radicincitans growth (flavonoids, carotenoids) was not altered either after E. radicincitans inoculation (data not shown).

\section{Discussion}

\section{Bacterial Growth Responses to Glucosinolate}

Concentration and Composition

The effect of changing carbon substrate composition on $E$. radicincitans indicates the strong interrelation between this enterobacterial strain and glucosinolate composition under nutrient-limited conditions. The distinct preference of $E$. radicincitans for alkenyl glucosinolates (exemplified by 2-propenyl standard and plant extracts containing a high 2-propenyl, 3-butenyl and 4-pentenyl concentration) in comparison with lower utilization of aromatic glucosinolates (exemplified by benzyl standard and plant extracts containing high 2-phenylethyl concentrations) might be due to the relatively easy cleavage of the double-bonded carbon in respect to carbon which is integrated in benzene ring systems. This glucosinolatespecific effect on bacterial growth in vitro was also found in vivo by Ruppel et al. [2008] as they demonstrated that the bacterial population density in the plant phyllosphere was positively correlated to the alkenyl glucosinolates 2propenyl, 3-butenyl and 4-pentenyl whereas the aromatic glucosinolate 2-phenylethyl showed a negative correlation to the phyllospheric bacterial population size. This glucosinolate specificity is underlined by calculating the effect of the main glucosinolates 2-propenyl, 3-butenyl, 4-pentenyl and 2-phenylethyl on the colonization ability of $E$. radicincitans by means of multiple regression analy- 
sis. It was clearly shown that 2-propenyl and 3-butenyl positively affected the colonization ability of the introduced bacterial strain and that 2-phenylethyl had a significant negative effect, while 4-pentenyl had no significant impact (table 6).

Moreover, no direct inhibition of bacterial growth occurred in nutrient solution by adding pure glucosinolates to the medium, which indicates that the glucosinolates themselves are nontoxic [Manici et al., 1997; Mithen et al., 1986].

\section{Colonization of Introduced E. radicincitans Cells in the Phyllosphere}

That E. radicincitans could not colonize the phyllosphere of N. officinale might be due to the high concentration of aromatic 2-phenylethyl as well as its breakdown products. Major degradation products - catalyzed by the endogenous thioglucosidase enzyme (myrosinase) - include isothiocyanates, thiocyanates, and nitriles [Mikkelsen et al., 2002; Rask et al., 2000], which are all known to have antimicrobial effects [Brader et al., 2001; Manici et al., 1997; Mari et al., 1993; Tierens et al., 2001], while glucosinolates themselves do not have bactericidal effects as shown in our pure culture experiments with aliphatic 2-propenyl, aromatic benzyl glucosinolates and cruciferous plant extracts. Myrosinase is stored in idioblastic myrosin cells, while glucosinolates are located in the cell vacuoles in the surrounding tissue [Bones and Rossiter, 1995; Chen and Andreasson, 2001]. Thus, the glucosinolatemyrosinase system is a physically separated two-component system and glucosinolate breakdown products are only generated by cell disruption occurring by wounding, chewing, or maceration by herbivores and microbes [Tierens et al., 2001]. As phyllospheric microorganisms can cause glucosinolate breakdown by metabolizing plant cell components, it was found that glucosinolate degradation products differ in their toxicity. Aromatic isothiocyanates are more toxic than aliphatic ones, resulting in higher antifungal activity [Manici et al., 1997; Sarwar et al., 1998]. The generally higher toxicity of aromatic isothiocyanates could also cause enhanced antibacterial activity, leading to the inability of E. radicincitans to colonize the phyllosphere of $N$. officinale that contains very high concentrations of the aromatic 2-phenylethyl glucosinolate compared to all other cruciferous species investigated in this study. Finally, Brader et al. [2006] demonstrated a 10 -fold reduction in bacterial growth by Pseudomonas syringae in transgenic Arabidopsis thaliana having an enhanced aromatic glucosinolate concentration. Moreover, the low colonization in the phyllosphere of $N$. officinale might also be caused by the relatively low levels of further carbon sources such as phyllospheric sugars and phyllospheric total carbon (table 4). The relatively low $\beta$-carotene concentration in the leaves (table 5) could also induce this low colonization effect as Ruppel et al. [2008] found a positive correlation between $\beta$-carotene concentration and microbial phyllospheric population since $\beta$-carotene, a precursor of vitamin A, mainly acts as microbial growth factor compared with other carotenoids. The distinct growth restriction of E. radicincitans in $N$. officinale might also be due to the markedly high level of quercetin (table 5) as quercetin was found to be a potential antibacterial [Li and $\mathrm{Xu}, 2008$ ] and antifungal agent [Skadhauge et al., 1997].

However, B. juncea, which contains a relatively high concentration of aliphatic glucosinolates such as 2-propenyl, shown to support bacterial growth in the in vitro experiment, was not colonized by $E$. radicincitans 6 weeks after inoculation of the plants. This inhibitory impact might be essentially due to the very hairy leaf surface of $B$. juncea which probably prevented the adhesion of $E$. radicincitans to the leaf surface and thus the colonization of the cells since bacterial adhesiveness highly depends on the surface constitution of the target [Andrews and Buck, 2002]. Moreover, the combination of medium concentrations of glucosinolates and kaempferol (tables 3, 5), which is an effective antimicrobial flavonoid too [Bloor, 1995; Sousa et al., 2008], suggests an additive suppressive effect of both phytochemicals on the growth of E. radicincitans.

In contrast to $B$. juncea, $B$. oleracea var. capitata was also characterized by 2-propenyl as the major glucosinolate, but at a distinctly low concentration, and this Brassica species was slightly colonized by E. radicincitans. Tierens et al. [2001] found that in Arabidopsis thaliana, older leaves containing higher aliphatic glucosinolate concentrations than younger ones had fewer severe microbial- or fungal-induced chlorosis symptoms. The accumulation of aliphatic glucosinolates also reduced the susceptibility of A. thaliana to Erwinia carotovora [Brader et al., 2006]. As increased concentrations of aliphatic glucosinolates reduced bacterial colonization, the low concentration of aliphatic 2-propenyl in B. oleracea var. capitata leaves might allow some colonization of $B$. oleracea var. capitata. The growth of $E$. radicincitans on $B$. oleracea var. capitata might also be supported by relatively high concentrations of phyllospheric monosaccharides and phyllospheric total carbon (table 4) acting as additional carbon sources and compensating for the antibacterial activity of the high kaempferol concentration (table 5). 
B. campestris was characterized by the highest colonization of its phyllosphere by E. radicincitans in comparison with the other species, despite the total glucosinolate concentration being nearly as high as in N. officinale. As in B. campestris the aliphatic 3-butenyl was the predominant glucosinolate, this colonization effect underlines the specific impact of individual glucosinolate breakdown products on microorganisms as aromatic isothiocyanates are more toxic than aliphatic isothiocyanates [Brader et al., 2006; Manici et al., 1997; Sarwar et al., 1998]. The high colonization of the leaves of B. campestris by E. radicincitans might also be due to other growth-promoting phytochemicals such as carotenoids [Ballows et al., 1992; Janzcik et al., 2006; Müller et al., 1998]. As B. campestris was also characterized by a high carotenoid concentration especially $\beta$-carotene - combined with moderate quercetin and kaempferol concentrations compared to all other investigated Brassica species, a distinct bacterial-colonization-supporting effect of carotenoids is suggested as demonstrated by Ruppel et al. [2008]. Isorhamnetin, the major flavonoid in B. campestris (table 5), seems to exert no suppressing effect on colonization by E. radicincitans, and no reference was found explicitly demonstrating antimicrobial activity of isorhamnetin. Moreover, its relatively high concentration in phyllospheric sugars, especially glucose and fructose, might also contribute to $E$. radicincitans growth in this plant phyllosphere.

In B. rapa var. alboglabra, two major aliphatic glucosinolates were found: 3-butenyl and methylsulfinylbutyl. Isothiocyanates of methylsulfinylbutyl are characterized by pronounced antimicrobial activity [Tierens et al., 2001], suggesting that the strong inhibition of E. radicincitans growth in B. rapa var. alboglabra could mainly be due to methylsulfinylbutyl glucosinolate. In addition, the high kaempferol concentration in B. rapa var. alboglabra indicates a pronounced antimicrobial effect as E. radicincitans growth was limited as was also the case for bacterial pathogens [Pourcel et al., 2006; Sousa et al., 2008].

\section{Effect of E. radicincitans Inoculation on Glucosinolate} Concentration

Bacterial pathogens such as E. carotovora cause considerable tissue damage and necrosis, leading to the formation of glucosinolate breakdown products [Tierens et al., 2001]. In contrast, Pseudomonas syringae cause only slight or no cell damage during pathogenesis, and thus do not induce the release of glucosinolates by host cell vacuoles or their myrosinase-dependent conversion to antibacterial breakdown products [Tierens et al., 2001], which also indicates that nonpathogenic Enterobacter strains might cause mild cell damage too by metabolizing plant cell components and releasing fewer glucosinolate degradation products. This slight mechanical cell disruption might be the reason why E. radicincitans inoculation did not induce a plant defense response, and thus a subsequent increase in glucosinolate concentration in the phyllosphere of the cruciferous species investigated here. However, in a study of $B$. rapa var. rapifera, we found a glucosinolate-stimulating influence of $E$. radicincitans if inoculated in combination with methyl jasmonate, which had been observed to lead to a synergistic increase in glucosinolate concentration [Sauder, 2006]. As methyl jasmonate is a signaling molecule and triggers a signal cascade that activates several defense responses including the synthesis of glucosinolates by affecting gene transcription [Mikkelsen et al., 2000], the combined inoculation of E. radicincitans and methyl jasmonate might induce an increased plant defense response.

Since glucosinolate concentration did not increase after $E$. radicincitans inoculation, we assume that $E$. radicincitans, an auxin-producing bacterium, did not stimulate glucosinolate biosynthesis via indole glucosinolates by additional bacterial auxin supply. One reason for this could be that there was insufficient bacterial auxin production to influence secondary plant metabolism or that auxin utilization by the plant mainly supported its development. Another reason could be that the inoculated bacterial cells were not able to colonize and persist in the phyllosphere although E. radicincitans grew in cruciferous plant extracts. Therefore, no bacterial-induced phytohormone supply was possible at least in 3 of the 5 plant species.

Since the investigated cruciferous species are economically important vegetables that contain various concentrations of glucosinolates, future crop management strategies designed to support plant growth and optimize glucosinolate concentrations - as interesting human health-promoting compounds - by using PGPB benefit from advances in our understanding of bacterial colonization in the cruciferous phyllosphere. The impact of aromatic and certain aliphatic glucosinolates observed in our study revealed that not only plant pathogens were affected in their growth by glucosinolates [Brader et al., 2001, 2006; Bending and Lincoln, 2000; Tierens et al., 2001], but also the native bacterial population [Ruppel et al., 2008] and even the PGPB as exemplified by E. radicincitans in the present study. The results of this study further confirm promotion or suppression of $E$. radicincitans colonization and persistence and provide detailed information on how this process is dependent on the 
plant's major individual glucosinolate - besides other physical and chemical factors - and its concentration as demonstrated in the phyllosphere of various cruciferous plants.

\section{Experimental Procedures}

Two experiments were carried out: an in vitro experiment as a bacterial pure culture experiment with glucosinolate standards and Brassica plant extracts to test the glucosinolate effect on bacterial growth responses, and a second experiment with inoculation of the PGPB E. radicincitans to 5 different species of the family Brassicaceae each characterized by a particular major aliphatic or aromatic glucosinolate and by different concentrations of indole glucosinolates to determine the colonization ability of $E$. radicincitans with respect to the glucosinolate composition of each plant.

Plants were grown in growth cabinets (plant pot experiment) to rigorously control growth conditions since environmental factors such as radiation and temperature are frequently observed to influence the concentration of glucosinolates in the plants [Milford and Evans, 1991; O'Callaghan et al., 2000; Sarwar and Kirgegaard, 1998; Schonhof et al., 2007; Schreiner, 2005].

\section{Plant Material and Experimental Design}

In vitro Experiment

A microplate bacterial pure culture experiment was conducted using a bacterial pure culture of $E$. radicincitans strain DSM 16656 [Kämpfer et al., 2005]. The experiment was conducted to analyze the ability of the bacteria to use the aliphatic glucosinolate 2-propenyl (Sigma-Aldrich Chemie GmbH, Taufkirchen, Germany) and the aromatic benzylglucosinolate (AppliChem $\mathrm{GmbH}$, Darmstadt, Germany) as carbon source in comparison to glucose + sucrose and to a control without carbon in minimal medium. Additionally, the leaf extracts obtained from 11 Brassica species containing different concentrations and compositions of glucosinolates were investigated. These selected Brassica species comprised the Brassica species of the plant pot experiment (B. juncea cv Red Giant, B. campestris cv Mibuna Early, B. oleracea var. capitata cv Türkis, and B. rapa var. alboglabra, N. officinale) which were supplemented by Brassica species, varieties or cultivars ( $B$. juncea cv Green in Snow, B. rapa var. rapifera, B. rapa, B. rapa ssp. chinensis, $B$. oleracea var. italica, $B$. oleracea var. botrytis) characterized by alternative glucosinolate concentrations or compositions (table 2).

Bacteria grown in standard I nutrient solution (Merck KGaA, Darmstadt, Germany) from exponential growth phase were washed twice by centrifugation at $8,000 \mathrm{~g}$ for $20 \mathrm{~min}$ in sterile $0.05 \mathrm{M} \mathrm{NaCl}$ solution to remove all other nutrients and carbon sources. $10 \mu$ l of the bacterial solution (optical density $\mathrm{A}_{620}=0.7$ ) was inoculated into $190 \mu \mathrm{l}$ minimal medium [Gerhardt et al., 1994] supplemented with $0.4 \mu \mathrm{g} \mathrm{N} \mu l^{-1}$ as $\mathrm{NH}_{4} \mathrm{NO}_{3}$ using microtiter plates. The glucosinolates 2-propenyl and benzyl and a mixture of glucose + sucrose were filter sterilized $(0.2 \mu \mathrm{m}$ Millipore, Billerica, Mass., USA) and applied at a final concentration of $4 \mu \mathrm{g}$ $\mathrm{C} \mu \mathrm{l}^{-1}$. Plant extracts were sterilized by microwave treatment [Song and Thornalley, 2007]. Sterile controls containing nitrogen and carbon sources were prepared to check the sterility in the absence of bacterial inoculates and were used as blanks. Plant extracts of 11 Brassica plants (10 $\mu$ l per well) were tested likewise. All treatments were replicated 6 times. Microtiter plates were covered by clear transparent lids and incubated at $30^{\circ} \mathrm{C}$ in a microplate reader (anthos htIII, Eugendorf, Austria) for 28 h. Bacterial kinetic growth was monitored photometrically at $620 \mathrm{~nm}$ every 10 min during the incubation time. Bacterial growth responses to phytochemicals and plant extracts were calculated versus growth on glucose + sucrose.

\section{Plant Pot Experiment}

Five plant species of the Brassicaceae family (B. juncea cv Red Giant, B. campestris cv Mibuna Early, B. oleracea var. capitata cv Türkis, and B. rapa var. alboglabra, N. officinale) characterized by a particular major aliphatic or aromatic glucosinolate and by different concentrations of indole glucosinolates (table 3) were inoculated with the PGPB strain E. radicincitans. The experiment was carried out in block design with 3 replicates in growth cabinets (type VB1014, Vötsch Industrietechnik GmbH, BalingenFrommern, Germany) under controlled climatic conditions of a $12: 12 \mathrm{~h}$ light/dark photoperiod, corresponding to a photosynthetic photon flux density of $400 \mu \mathrm{mol} \mathrm{m}^{-2} \mathrm{~s}^{-1}, 70-80 \%$ relative humidity, and $15 / 10^{\circ} \mathrm{C}$ day/night temperature. Five plants each of $B$. juncea, B. campestris, B. oleracea var. capitata, and B. rapa var. alboglabra were grown in pots with $600 \mathrm{~g}$ substrate. For N. officinale, 25 seeds were placed in one 600 -gram pot. A total of $225 \mathrm{mg}$ nitrogen per pot was added. For each species, 6 pots were used for each replicate. Water was supplied according to the requirements of the plants. Plants were harvested at the 6-leaf stage.

Bacterial cells of $E$. radicincitans were grown in standard nutrient solution (Merck KGaA, Darmstadt, Germany) at $29^{\circ} \mathrm{C}$ in a rotary incubator at $100 \mathrm{rpm}$ for $48 \mathrm{~h}$. To remove all additional nutrients, bacterial cells were washed twice in sterile tap water by centrifugation at $8,000 \mathrm{~g}$ for $20 \mathrm{~min}$ before inoculation. Plants were inoculated with $10^{8}$ cells per plant by spraying the bacterial suspension onto the plant leaves when two leaves had emerged. Control plants were inoculated with sterile tap water only.

Quantification of E. radicincitans using a Species-Specific TaqMan Probe and the Plant Housekeeping TEF Gene

$16 \mathrm{~S}$ rDNA (E. radicincitans-specific) and housekeeping TEF (plant-specific) gene copy numbers were determined for the same plant sample using two different real-time PCR procedures. E. radicincitans gene copy number was determined using a Taq$\mathrm{Man}^{\mathrm{TM}}$ assay and a species-specific probe, while the TEF gene copy numbers were measured using the SybrGreen I approach. Primer probe design and PCR conditions were as described earlier [Ruppel et al., 2006]. DNA was extracted from $10 \mathrm{mg}$ freezedried leaf material using the DNeasy Plant Mini Kit (Qiagen, Hilden, Germany). DNA concentration was measured photometrically at $260 \mathrm{~nm}$ (Nanodrop ND1000, Technology Inc., Wilmington, Del., USA) and quality was checked photometrically by the $\mathrm{A}_{260} / \mathrm{A}_{280}$ ratio calculation to be between 1.9 and 2.1 and the $A_{320}$ measurement was nearly 0 . The colonization of inoculated $E$. radicincitans cells was calculated using the $\Delta \Delta \mathrm{C}_{\mathrm{t}}$ method, shown as $\mathrm{x}$-fold increase of $E$. radicincitans cells in the inoculated treatment samples relative to the noninoculated control sample and normalized to the reference gene (housekeeping TEF gene) [Livak and Schmittgen, 2001]. 


\section{Sample Preparation}

A mixed sample of 30 plants of each cultivar of the leafy Brassica vegetables and 300 plants of $N$. officinale was used from each replication $(n=3) .15 \mathrm{~g}$ of fresh matter of leaves was used for each carotenoid and sugar analyses. For glucosinolate and flavonoid determination, about $200 \mathrm{~g}$ fresh matter of leaves was immediately deep frozen $\left(-40^{\circ} \mathrm{C}\right)$, freeze-dried, and then the dry matter was finely ground.

\section{Glucosinolate Analysis}

The HPLC method reported by Krumbein et al. [2005] was used for glucosinolate determination. Duplicates of freeze-dried sample material $(0.5 \mathrm{~g})$ were heated to and incubated at $75^{\circ} \mathrm{C}$ for $1 \mathrm{~min}$, extracted with $4 \mathrm{ml}$ of a methanol/water mixture $(\mathrm{v} / \mathrm{v}=$ $7: 3$, at $70^{\circ} \mathrm{C}$ ), and then, after adding $1 \mathrm{ml} 0.4 \mathrm{M}$ barium acetate, centrifuged at 4,000 rpm for $10 \mathrm{~min}$. For an internal standard, 200 $\mu \mathrm{l}$ of a $5 \mathrm{~mm}$ stock solution of sinigrin in methanol was added to one of the duplicates just before the first extraction. The residue was extracted twice more with $3 \mathrm{ml}$ of the methanol/water mixture $\left(\mathrm{v} / \mathrm{v}=7: 3,70^{\circ} \mathrm{C}\right)$. The supernatants were pooled and made up to $10 \mathrm{ml}$ with the methanol/water mixture $\left(\mathrm{v} / \mathrm{v}=7: 3,70^{\circ} \mathrm{C}\right)$. From this, $5 \mathrm{ml}$ of the extract was applied to a $250-\mu$ l DEA-Sephadex A-25 ion exchanger (acetic acid-activated, Sigma-Aldrich Chemie) and rinsed with $10 \mathrm{ml}$ bidistilled water. Next, $250 \mu \mathrm{l}$ of a purified solution of aryl sulfatase (Boehringer-Mannheim $\mathrm{GmbH}$, Mannheim, Germany) was applied and left for $12 \mathrm{~h}$ before flushing the desulfocompounds with $5 \mathrm{ml}$ bidistilled water. Desulfoglucosinolate analysis was conducted by HPLC (Merck Hitachi, Darmstadt, Germany) using a Spherisorb ODS2 column $(5 \mu \mathrm{m}$, $250 \times 4 \mathrm{~mm})$. A gradient of $0-20 \%$ acetonitrile in water was selected (2-34 min), followed by $20 \%$ acetonitrile in water (up to 40 $\mathrm{min}$ ), and then $100 \%$ acetonitrile (10-50 $\mathrm{min})$. Determination was conducted at a flow of $1.3 \mathrm{ml} \cdot \mathrm{min}^{-1}$ and a wavelength of $229 \mathrm{~nm}$. Desulfoglucosinolates were identified by HPLC-APCI-MS ${ }^{2}$ using Agilent 1100 series in the positive ionization mode [Krumbein et al., 2005; Zimmermann et al., 2007]. Glucosinolate concentration was calculated using 2-propenyl glucosinolate as internal and external standard and the response factor of each compound relative to 2-propenyl glucosinolate. Glucosinolates were assessed in duplicate.

\section{Flavonoid Analysis}

Flavonoids were determined as their aglycones after acid hydrolysis as described in Krumbein et al. [2007]. $40 \mu$ l of $62.5 \%$ aqueous methanol was added to $0.5 \mathrm{~g}$ of the freeze-dried sample. $10 \mathrm{ml}$ of $8 \mathrm{M} \mathrm{HCl}$ was added to this extract. Thus, the extraction solution consisted of $1.6 \mathrm{M} \mathrm{HCl}$ in $50 \%$ aqueous methanol (v/v). After refluxing at $90^{\circ} \mathrm{C}$ for $2 \mathrm{~h}$, the extract was allowed to cool, was adjusted to $100 \mathrm{ml}$ with $50 \%$ methanol, and sonicated for $5 \mathrm{~min}$. The extract was then filtered through a $0.45-\mu \mathrm{m}$ filter for HPLC analyses.

The flavonol composition (quercetin, kaempferol, isorhamnetin) and concentration were determined using a series 1100 HPLC (Agilent, Waldbronn, Germany) equipped with a diode array detection system. A Prodigy column ODS(3) $(250 \times 4.6 \mathrm{~mm}, 5 \mu \mathrm{m}$, $100 \AA$ ) (Phenomenex, Aschaffenburg, Germany) was used with a security guard $\mathrm{C} 18(4 \times 3.0 \mathrm{~mm})$ at a temperature of $25^{\circ} \mathrm{C}$. Solvent $A$ was water $+0.1 \%$ trifluoroacetic acid $+2 \%$ tetrahydrofuran; solvent $\mathrm{B}$ was acetonitrile. The following gradient was used: $30-35 \%$ B (5 min), 35-39\% B (12 min), 39-90\% B (5 min), 90\% B isocratic ( $2 \mathrm{~min}$ ), $90-30 \% \mathrm{~B}$ ( $5 \mathrm{~min}$ ), $30 \% \mathrm{~B}$ isocratic (5 min). The chromatograms were monitored at $270 \mathrm{~nm}$ with a flow rate of $1 \mathrm{ml} \cdot \mathrm{min}^{-1}$. Contents were quantitatively determined by calibration curves of the related pure standards. Flavonols were identified by HPLC-ESI-MS ${ }^{2}$, using Agilent 1100 series in the negative ionization mode [Krumbein et al., 2007].

\section{Carotenoid Analysis}

Carotenoids (lutein, $\beta$-carotene) were also determined by HPLC [Krumbein et al., 2005]. To $15 \mathrm{~g}$ of cut plant material, $1 \mathrm{~g}$ calcium carbonate, $30 \mathrm{~g}$ sodium sulfate and $30 \mathrm{ml}$ acetone were added, and the samples were homogenized for $2 \mathrm{~min}$. The extract was then filtered under suction, and the solid materials were extracted repeatedly with acetone until the resulting filtrate was colorless. The extract was then filtered through a $0.45-\mu \mathrm{m}$ filter for HPLC analysis. Carotenoid concentrations were determined by HPLC using a C-18 reversed-phase column Lichosphere 100 $(5 \mu \mathrm{m}, 250 \times 4 \mathrm{~mm}$; Merck) with an isocratic eluent of $75 \%$ acetonitrile, $15 \%$ methanol and $10 \%$ methylene chloride. The analysis was carried out at a flow rate of $1 \mathrm{ml} \cdot \mathrm{min}^{-1}$. Wavelengths of 448 and $455 \mathrm{~nm}$ were used to determine lutein and $\beta$-carotene, respectively. Concentrations were determined quantitatively by calibration curves of the related pure standards. Chemical analyses were performed in duplicate.

Sugar Analysis

The concentrations of various free sugars (glucose, fructose, sucrose) were analyzed enzymatically [Boehringer Mannheim, 1989].

\section{Nitrogen and Carbon Analysis}

For the nitrogen and carbon analyses, finely ground samples were burned in the element analyzer Vario EL (Elemtar Analysensysteme GmbH, Hanau, Germany) using Dumas' burning method [VDLUFA, 1991]. Total nitrogen and carbon concentrations were also assessed in duplicate.

\section{Statistical Analysis}

Comparison of mean values of 3 or 4 replicates was performed using ANOVA and Tukey's HSD test at a $\mathrm{p} \leq 0.05$. Using the REG procedure, linear multiple regression analysis based on the F test was conducted at a significance level of $\mathrm{p} \leq 0.05$. All calculations were carried out using the software package Statistica for Windows (version 6.1, Statsoft Inc. 2001).

\section{Acknowledgements}

This research was supported by the German Federation and the Federal States Brandenburg and Thuringia. We would like to thank A. Jankowsky for her phytochemical analyses, B. Wernitz for her microbial work and E. Büsch, U. Zentner, and A. Maikath for their technical assistance. 


\section{References}

Andrews JH, Buck W: Adhesion of yeasts to leaf surfaces; in Lindow SE, Hecht-Pionar EI, Elliott VJ (eds): Phyllosphere Microbiology. St Paul, APS Press, 2002, pp 53-68.

- Bak S, Tax FE, Feldmann KA, Galbraith DW, Feyereisen RR: CYP83B1, a cytochrome $\mathrm{P} 450$ at the metabolic branch point in auxin and indole glucosinolate biosynthesis in Arabidopsis. Plant Cell 2001;13:101-111.

Ballows A, Trüper HG, Dworkin M, Harder W, Schleifer KH: The Prokaryotes; in Ballows et al (eds): Handbook on the Biology of Bacteria: Ecophysiology Isolation, Identification, Application. Berlin, Springer Verlag, 1992, vol 1, pp 157-158.

Behr HC: ZMP-Marktbilanz Gemüse 2006. Zentrale Markt- und Preisberichtstelle GmbH, Bonn, Germany, 2006.

Bending GD, Lincoln SD: Inhibition of soil-nitrifying bacteria communities and their activities by glucosinolate hydrolysis products. Soil Biol Biochem 2000;32:1261-1269.

-Bloor SJ: An antimicrobial kaempferol-diacylrhamnoside from Pentachondra pumila. Phytochemistry 1995;38:1033-1035.

-Bones AM, Rossiter JT: The myrosinase-glucosinolate system, its organisation and biochemistry. Physiol Plant 1995;97:194-208.

Boehringer Mannheim: Methoden der enzymatischen Lebensmittelanalytik. Mannheim, Boehringer Mannheim, 1986.

- Brader G, Mikkelsen MD, Halkier BA, Palva ET: Altering glucosinolate profiles modulates disease resistance in plants. Plant J 2006;46: 758-767.

Brader G, Tas E, Palva ET: Jasmonate-dependent induction of indole glucosinolates in Arabidopsis by culture filtrates of the nonspecific pathogen Erwinia carotovora. Plant Physiol 2001;126:849-860.

Chen SX, Andreasson E: Update on glucosinolate metabolism and transport. Plant Physiol Biochem 2001;39:743-758.

Gerhardt P, Murray RGE, Wood WA, Krieg NR: Methods for general and molecular bacteriology. Washington, American Society for Microbiology, 1994.

-Halkier BA, Du L: The biosynthesis of glucosinolates. Trends Plant Sci Rev 1997;2:425-431.

Höflich G, Ruppel S: Growth stimulation of pea after inoculation with associative bacteria. Microbiol Res 1994;149:99-104.

Janczik H, Schreiner M, Krumbein A, Schonhof I, Huyskens-Keil S, Ruppel S: Signalwirkung der Glucosinolat- und Carotinoidzusammensetzung auf die natürliche bakterielle Besiedlung verschiedener Gemüsearten. Proc 43th Conference of Hortic Sci, Potsdam, 2006, p 195.

-Kämpfer P, Ruppel S, Remus R: Enterobacter radicincitans sp Nov., a plant growth promoting species of the family Enterobacteriaceae. System Appl Microbiol 2005;28:213-221.
Krumbein A, Saeger-Fink H, Schonhof I: Changes in quercetin and kaempferol concentrations during broccoli head ontogeny in three broccoli cultivars. J Appl Bot Food Qual 2007:81:136-139.

Krumbein A, Schonhof I, Schreiner M: Composition and contents of phytochemicals (glucosinolates, carotenoids and chlorophylls) and ascorbic acid in selected Brassica species (B. juncea, B. rapa subsp. nipposinica var. chinoleifera, B. rapa subsp. chinensis, $B$. rapa subsp. rapa). Appl Bot Food Qual 2005;79: 168-174.

Li MY, Xu ZT: Quercetin in a lotus leaves extract may be responsible for antibacterial activity. Arch Pharm Res 2008;5:640-644.

Lindow SE, Hecht-Pionar EI, Elliott VJ: Phyllosphere Microbiology. St Paul, APS Press, 2002.

Livak KJ, Schmittgen TD: Analysis of relative gene expression data using real-time quantitative PCR and the $2^{-\Delta \Delta \mathrm{C}_{\mathrm{T}}}$ method. Methods 2001;25:402-408.

Manici LM, Lazzeri I, Palmieri S: In vitro fungitoxic activity of some glucosinolates and their enzyme-derived products towards plant pathogenic fungi. Agric Food Chem 1997;45:2768-2773.

Mari M, Iori R, Leoni O, Marchi A: In-vitro activity of glucosinolate-derived isothiocyanates against postharvest fruit pathogens. Ann Appl Biol 1993;123:155-164.

Mikkelsen MD, Hansen CH, Wittstock U, Halkier BA: Cytochrome P450 CYP79B2 from Arabidopsis catalyzed the conversion of tryptophan to indole-3-acetaldoxime, a precursor of indole glucosinolates and indole-3acetic acid. J Biol Chem 2000;275:3371233717.

- Mikkelsen MD, Petersen BL, Glawischnig E, Jensen AB, Andreasson E, Halkier BA: Modulation of CYP79 genes and glucosinolate profiles in Arabidopsis by defense signaling pathways. Plant Physiol 2003;131:298-308.

Mikkelsen MD, Petersen BL, Olsen CE, Halkier BA: Biosynthesis and metabolic engineering of glucosinolates. Amino Acids 2002;22: 279-295.

Milford GFJ, Evans EJ: Factors causing variation in glucosinolates in oilseed rape. Outlook Agric 1991;20:31-37.

-Mithen RF, Lewis BG, Fenwick GR: In vitro activity of glucosinolates and their products against Leptosphaeria maculans. Trans $\mathrm{Br}$ Mycol Soc 1986;87:433-440.

Monteiro A, Lunn T: Trends and perspectives of vegetable brassica breeding world-wide. World Conf Horticult Res 1999;495:273279.

Müller C: Nährstoffe - Power für die Abwehr. UGB-Forum 1998;5:250-253.
O'Callaghan KJ, Stone PJ, Hu X, Griffiths DW, Davey MR, Cocking EC: Effects of glucosinolates and flavonoids on colonization of the roots of Brassica napus by Azorhizobium caulinodans ORS571. Appl Environ Microbiol 2000;5:2185-2191.

- Pourcel L, Routaboul JM, Cheynier V, Lepiniec L, Debeaujo I: Flavonoid oxidation in plants: from biochemical properties to physiological functions. Trends Plant Sci 2006;12:2936.

- Rask I, Andreasson E, Ekbom B, Eriksson S, Pontoppidan B, Meijer J: Myrosinase: gene family evolution and herbivore defense in Brassicaceae. Plant Mol Biol 2000;42:93113.

Rodman JE, Karol KG, Price RA, Sytsma KJ: Molecules, morphology, and Dahlgren's expanded order Capparales. Syst Bot 1998;21: 289-307.

Ruppel S: Bedeutung der Rhizosphären- und endophytischen Bakterien für die Pflanzenernährung. Arch Acker Pfl Boden 2000;45: 329-341.

Ruppel S, Hecht-Buchholz C, Remus R, Ortmann U, Schmelzer R: Settlement of the diazotrophic, phytoeffective bacterial strain Pantoea agglomerans on and within winter wheat - an investigation using ELISA and transmission electron microscopy. Plant Soil 1992;145:261-273.

Ruppel S, Krumbein A, Schreiner M: Composition of the phyllospheric microbial populations on vegetable plants with different glucosinolate and carotenoid compositions. Microb Ecol 2008;56:364-372.

Ruppel S, Rühlmann J, Merbach W: Quantification and localization of bacteria in plant tissues using quantitative real-time PCR and online emission fingerprinting. Plant Soil 2006;286:21-35

Ruppel S, Wernitz B: Quantifizierung und Monitoring von Pantoea agglomerans an Kohlrabi Wurzeln und Blättern mittels Real-time PCR; in Merbach W, Egle K, Augustin J (eds): Wurzelinduzierte Bodenvorgänge. 14. Borkheider Seminar zur Ökophysiologie des Wurzelraumes. Stuttgart/Leipzig/Wiesbaden, Teubner, 2004, pp 56-61.

- Sarwar M, Kirkegaard JA: Biofumigation potential of Brassicas. II. Effect of environment and ontogeny on glucosinolate production and implications for screening. Plant Soil 1998;201:91-101.

- Sarwar M, Kirkegaard JA, Wong PT, Desmarchelier JM: Biofumigation potential of Brassicas: In vitro toxicity of isothiocyanates to soilborne fungal pathogens. Plant Soil 1998;201: 103-112.

Sauder S: Vergleich von Kultivierungstechnologien (Hydro- und Wurzelkulturen) zur Gewinnung von Glucosinolaten; Master Diss, Technical University Berlin, 2006. 
Scholz-Seidel C, Ruppel S: Nitrogenase- and phytohormone activities of Pantoea agglomerans in culture and their reflection in combination with wheat plants. Zentralbl Mikrobiol 1992;147:319-328.

Schonhof I, Kläring H, Krumbein A, Claussen W, Schreiner M: Effect of temperature increase under low radiation conditions on phytochemicals and ascorbic acid in broccoli. Agric Ecol Environ 2007;119:103-111.

-Schreiner M: Vegetable crop management strategies to increase the quantity of phytochemicals. Eur J Nutr 2005;44:85-94.

-Schreiner M, Huyskens-Keil S: Phytochemicals in fruit and vegetables: health promotion and postharvest elicitors. Crit Rev Plant Sci 2006;25:267-278.
-Skadhauge B, Thomsen K, Wettstein D: The role of barley testa layer and its flavonoid content in resistance to Fusarium infections. Hereditas 1997;126:147-160.

Song L, Thornalley PJ: Effect of storage, processing and cooking on glucosinolate content of Brassica vegetables. Food Chem Toxicol 2007;45:216-224.

- Sousa C, Taveira M, Valentao P, Fernandes F, Pereira JA, Estevinho L, Bento A, Ferreres F, Seabra RM, Andrade PB: Inflorescences of Brassicacea species as source of bioactive compounds: a comparative study. Food Chem 2008;110:953-961.

Talalay P, Fahey JW: Phytochemicals from cruciferous plants protect against cancer by modulating carcinogen metabolism. J Nutr 2001;131:3027-3033.
Tierens FM, Thomma BP, Brouwer M, Schmidt J, Kistner K, Porzel A, Mauch-Mani B, Cammue BP, Broekaert WF: Study on the role of antimicrobial glucosinolate-derived isothiocyanates in resistance of Arabidopsis to microbial pathogens. Plant Physiol 2001;125: 1688-1699.

VDLUFA: Method Book I. Darmstadt, VDLUFAVerlag (Verband deutscher landwirtschaftlicher Untersuchungs- und Forschungsanstalten), 1991

Zimmermann N, Gerendás J, Krumbein A: Identification of desulphoglucosinolates in Brassicaceae by LC/MS/MS: Comparison of electrospray ionisation and atmospheric pressure chemical ionisation mass spectrometry. Mol Nutr Food Res 2007;51:1537-1546. 